\title{
Прояви семіотики гострого апендициту залежно від його розташування та триместру у вагітних
}

\begin{abstract}
Мета роботи: провести аналіз клінічного перебігу гострого апендициту та лабораторних показників запалення у вагітних залежно від розташування апендиксу та триместру вагітності для визначення тактики лікування та попередження ускладнень при вагітності.

Матеріали і методи. Оцінено клінічний перебіг та параклінічні показники у 258 вагітних із гострим апендицитом, що перебували на лікуванні в клінічних лікарнях міста Києва та 391 вагітна без гострої хірургічної патології, що склали групу порівняння. Серед біохімічних даних досліджено рівень імуноглобулінів М, G, A, Е, циркулюючих імунних комплексів, фактора некрозу пухлин, кріоглобулінів, прокальцитоніну, інтерлейкіну-1, 2, а також показників неспецифічної резистентності організму та адаптаційного імунітету.

Результати досліджень та їх обговорення. Раптовий початок болю спостерігали в I триместрі в 68,57 \% пацієнток, в II - 63,68 \% та 69,7 \% в третьому. Поєднання з нудотою та одно- або дворазовим блюванням встановлено в 77,14 \%, 47,89 \% та 36,36 \%, відповідно. Ознаки ендогенної інтоксикації встановлено у 20,0%, 45,26 \%, 57,58 \% вагітних у трьох триместрах відповідно. В II та III триместрах вагітності визначення болючості в точках Мак-Бурнея, Ланца було неефективне в 90 \% випадків. Серед біохімічних показників встановлено підвищення вмісту прокальцитоніну в 4 рази, концентрації ФНП - 2,74 раза, вмісту Іл-1 в 1,6 раза, вмісту ЦІК в 1,46 та рівнів IgM i IgG (в 2,11 раза та 1,37 раза, відповідно) щодо показників контрольної групи.
\end{abstract}

Ключові слова: гострий апендицит; вагітність; імуноглобуліни; інтерлейкіни; кріоглобуліни.

Постановка проблеми і аналіз останніх досліджень та публікацій. Початок та перебіг багатьох ГХЗ ОЧП у вагітних дуже часто відрізнявся атиповою клінічною картиною, котра була стертою, невираженою або замаскованою під інші захворювання, в тому числі гестози вагітних. До клінічних труднощів діагностики гострої хірургічної патології відносили схожість початку та розгорнутої клінічної картини з деякими станами акушерської практики - нудота та блювання вагітних, загрожуючий аборт, аборт, котрий розпочався, відшарування нормально розташованої плаценти, передчасні пологи, розрив матки, порушена ектопічна вагітність, перекрути маткової труби та яєчника. Кожна з розглянутих форм гострої хірургічної патології органів черевної порожнини мала певні особливості [1-9].

Мета роботи: зіставлення семіотики гострого апендициту залежно від триместру вагітності для визначення тактики лікування та попередження ускладнень при вагітності.

Матеріали і методи. У період із січня 2004 до грудня 2010 р. у хірургічне відділення міської клінічної лікарні № 3 м. Києва та за перше півріччя 2012 року в хірургічне відділення № 1 міської клінічної лікарні № 1 м. Києва було госпіталізовано 864 вагітні жінки. Всі вагітні були розділені на дослідну та контрольну групи. Вагітні контрольної групи проліковані в період із 2004 до 2007 р., досліджува- ної - з 2008 до 2012 р. Контрольну групу склали 391 вагітна, що складає 45,25 \% від всіх пролікованих вагітних жінок. Дослідна група - 473 вагітних, що склало 54,75 \% від загальної кількості госпіталізованих вагітних. Дані відображено на рисунку 1.

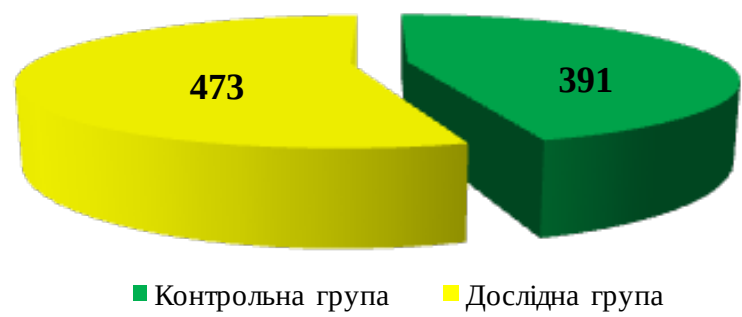

Рис. 1. Розподіл усіх пролікованих вагітних на контрольну (n=391) та дослідну групи (n=473).

При дослідженні контрольної та дослідної груп стосовно їх репрезентативності встановлено наступні дані. Так, середній вік в контрольній групі становить $(25,23 \pm 4,91)$ року $(16-45$ років), в дослідній - $(25,36 \pm 4,46)$ року (16-41 рік). Середній термін вагітності в контрольній групі складав $(22,16 \pm 7,1)$ тижня $(2-37$ тижнів), в дослідній - $(21,5 \pm 7,34)$ тижня (5-39 тижнів). Середній ліжко-день у контрольній групі склав $(3,97 \pm 2,58)$ ліжко-дня (1-14 ліжко-днів), в дослідній - $(4,11 \pm 2,38)$ ліжко-дня (1-10 ліжко-днів).

Контрольна та дослідна групи репрезентативні (Two-sample Wilcoxon rank-sum (Mann-Whitney) test): 
- за віком - z = -0,606; Prob $>|z|=0,5287$;

- за ліжко-днем - z = - 0,749; Prob $>|z|=0,454$.

За увесь період спостережень встановлено структуру захворюваності вагітних, пролікованих у хірургічних відділеннях КМКЛ № 3 та КМКЛ № 1. Отримані результати наведено у таблиці 1.

Результати досліджень та їх обговорення. У діагностиці гострого апендициту та інших гострих хірургічних захворювань враховували, що такі симптоми, як нудота, блювання, відсутність апетиту характерні не тільки для ГА, а і для ранніх гестозів і переважно трапляються в першому триместрі вагітності. Тому наявність даних симптомів часто становила певні труднощі в диференційній діагностиці ГА. Найбільш стабільним симптомом ГА у вагітних був біль. При оцінці болю враховували термін гестації та положення апендикса. Симптоми загрози переривання вагітності, котрі часто супроводжували ГА, а інколи повністю маскували основне захворювання. Також звертали увагу на локалізацію та характер болю, ірадіацію, зміщення протягом певного часу з місця первинного розташування, інтенсивність та тривалість больового синдрому.

Провідною скаргою у вагітних із ГА в обох групах був біль в животі, який спостерігали у 255 вагітних $(98,84$ \%; n = 258) (p <0,05). Раптовий початок болю спостерігали у 164 вагітних (63,57%; $\mathrm{n}=258)(\mathrm{p}<0,05)$. В I триместрі більшість вагітних вказувала на раптовий початок болю в правій здухвинній ділянці - 24 (68,57 \%; n = 35) (р <0,05) вагітних. У II та III триместрах біль раптово виникав біля пупка або в епігастрі та через 3-4 год змістився в зону проекції сліпої кишки. Так, у II триместрі дану закономірність спостерігали у 121 вагітної $(63,68 \% ; n=190)(\mathrm{p}<0,05)$, в III - 23 вагітних $(69,7$ $\%, n=33)(p<0,05)$. Зі слів хворих, інтенсивність больового синдрому була менш виражена в II та III триместрах вагітності, що зумовлено значним перерозтягненням передньої черевної стінки, і про- являвся у хворих як тупий, ниючий біль - у 116 $(61,05 \% ; n=190)(p<0,05)$ та у $20(60,61 \% ; n=33)$ (p <0,05) вагітних відповідно. 141 вагітна (54,65 \%; $\mathrm{n}=258)(\mathrm{p}<0,05)$ незалежно від терміну гестації вказувала, що біль посилюється при покашлюванні, ході і зміні положення тіла, а також ірадіює в праву нижню кінцівку, поперекову ділянку справа, праве підребер’я. Остання залежність була більш виражена з розвитком та наростанням деструктивних змін в червоподібному відростку та місцевих запальних змін парієтальної очеревини. Так, дані клінічні особливості спостерігали у 122 (83 \%; $\mathrm{n}=147)(\mathrm{p}<0,05)$ вагітних із деструктивною формою ГА і лише у 41 (36,94 \%; n = 111) (p <0,05) вагітних із катаральною формою ГА.

У діагностиці ГА враховували наявність дискінезій шлунково-кишкового тракту (закрепи, діарея та метеоризм), хоча самостіної діагностичної цінності вони не мають і тому враховувались лише в симптомокомплексі. Для типового розміщення гострого апендициту в I триместрі було характерне одно- або дворазове послаблення випорожнення, в II та III триместрах дану залежність не спостерігали.

У І триместрі поєднання абдомінального болю з нудотою та блюванням диференціювалась із гестозом першої половини вагітності та загрозою переривання вагітності. При ГА нудота та блювання переважно були одно- або дворазово, виникали раптово одразу після нападу болю, не залежали від приймання їжі та часу доби, після чого пацієнти відчували полегшення, що, у свою чергу, не характерно для гетсозу першої половини вагітності. В другій половині вагітності, а особливо в III триместрі, поєднання больового синдрому та нудоти з багаторазовим блюванням, після чого пацієнти не відчували полегшення, свідчило на користь гестозу другої половини вагітності - прееклампсії. Головними ознаками диференційної діагностики з ГА в цьому випадку були периферійні набряки, підвищений артеріальний тиск, знижений добовий діурез.

Таблиця 1. Структура захворюваності вагітних за увесь період спостережень 2004-2012 pp. (n= 864)

\begin{tabular}{||l|c|c||}
\hline \multicolumn{1}{|c|}{ Нозологія } & Кількість хворих (абсолютна) & Кількість хворих (\%) \\
\hline Гострий апендицит & 258 & 12,96 \\
\hline Гострий панкреатит & 112 & 7,04 \\
\hline Гострий холецистит & 61 & 2,55 \\
\hline Кишкова непрохідність & 22 & 2,8 \\
\hline Гінекологічна патологія & 24 & 3,94 \\
\hline Патологія нирок & 34 & 3 \\
\hline Інша патологія & 26 & 37,85 \\
\hline Виключено діагноз ГХЗ ОЧП & 327 & 100 \\
\hline Всього & 864 & \\
\hline
\end{tabular}


Таким чином, біль у животі поєднувався з нудотою та одно- або дворазовим блюванням, які виникали одразу після нападу болю, не залежали від приймання їжі та часу доби і хворі відчували полегшення, що, у свою чергу, не характерно для гестозу першої половини вагітності. Така закономірність характрена для 27 вагітних у I триместрі, що склало 77,14 \% (n = 35) (p <0,05), в II триместрі - для 91 вагітної $(47,89 \%$; $=190)(\mathrm{p}<0,05)$ і в III триместрі - для 12 вагітних $(36,36 \% ; n=33)(p<0,05)$.

Поєднання таких ознак ендогенної інтоксикації, як субфебрильна або фебрильна температура, спрага, тахікардія 90-100 уд./хв прямо корелювало з тривалістю больового нападу та вираженістю деструктивних змін в апендиксі і характерне для вагітних із деструктивними формами ГА. Дану клінічну особливість виявлено у 78 (53,06 \%; $\mathrm{n}=147)(\mathrm{p}<0,05)$ вагітних із деструктивною формою ГА і лише у $34(30,63 \%$; $=111)(\mathrm{p}<0,05)$ вагітних із катаральною формою ГА. 3 них в I триместрі - у 7 вагітних $(20 \%$; $=35)(\mathrm{p}<0,05)$, в II триместрі - у $86(45,26 \%$; $=190)(\mathrm{p}<0,05)$, в III триместрі у $19(57,58 \%$; $=33)(\mathrm{p}<0,05)$ вагітних.

Поєднання таких ознак ендогенної інтоксикації, як субфебрильна або фебрильна температура, спрага, тахікардія 90-100 уд./хв прямо корелювало $з$ тривалістю больового нападу та вираженістю деструктивних змін в апендиксі і характерне для вагітних із деструктивними формами ГА. Дану клінічну особливість виявлено у 78 (53,06 \%; $\mathrm{n}=147)(\mathrm{p}<0,05)$ вагітних із деструктивною формою ГА і лише у $34(30,63 \%$; $n=111)(\mathrm{p}<0,05)$ вагітних із катаральною формою ГА. 3 них в I триместрі - у 7 вагітних $(20 \%$; n = 35) $(\mathrm{p}<0,05)$, в II триместрі - у $86(45,26 \%$; $=190)(\mathrm{p}<0,05)$, в III триместрі у $19(57,58 \%$; $=33)(\mathrm{p}<0,05)$ вагітних.

Окремим важливим питанням $є$ пальпація живота вагітної при ГА. Про зменшення чутливості передньої черевної стінки в II триместрі після 20 тижня гестації та особливо в III триместрі внаслідок перерозтягнення її вагітною маткою, морфологічні зміни в м'язовій тканині під впливом прогестерону та зміну топографо-анатоміних співвідношень вагітної вже було зазначено вище. Тому в II та III триместрах вагітності визначення болючості в точках Мак-Бурнея, Ланца тощо не було ефективним (в 90 \% випадках). Зміщення вагітною маткою передньої черевної стінки від органів черевної порожнии, особливо в III триместрі, призводить до того, що симптоми подразненя очеревини були менш вираженими або були зовсім відсутніми. При фізикальному обстеженні вагітних із ГА болючість в точках Мак-Бурнея, Ланца визначалась лише в I триместрі і була характерна для 27 вагітних (77,14 \%; n = 35), в II триместрі - в 34 вагітних $(17,89 \%$; $=190)$ і в III триместрі у 4 вагітних $(12,12 \% ; n=33)$.

Симптом Щьоткіна-Блюмберга спостерігали у $160(62,02 \%$; $n=258)$ вагітних. 3 них у 131 вагітної (89,12 \%; $n=147)$ із деструктивною формою ГА і в 29 випадках $(26,13 \%$; $n=111)$ із катаральним ГА. У І триместрі позитивний симптом Щьоткіна-Блюмберга виявлено у 24 вагітних (68,57 \%; n = 35), в II триместрі у 128 вагітних $(67,37 \%$; $\mathrm{n}=190)$ і в III триместрі у 8 вагітних (30,3\%; $\mathrm{n}=33)$.

Симптом Кохера-Волковича був позитивний у 144 вагітних (55,8 \%; n = 258). 3 них у II триместрі у 121 вагітної (63,68 \%; n = 190), в III - у 23 вагітних (69,7 \%; n = 33). Для I триместру даний симптом не характерний. Необхідно зазаначитти, що у 91 вагітної (63,19 \%; n = 144) при позитивному симптомі Кохера-Волковича виявлено деструктивну форму ГА.

Симптом Брендо встановлено у 175 вагітних (67,83 \%; n = 258) і характерний для II триместру - 145 вагітних $(76,32 \% ; n=190)$ та III триместру - 30 вагітних $(90,91 \%$; $n=33)$. Симптом Брендо встановлено у 84 хворих із деструктивною формою ГА (48 \%; $\mathrm{n}=175)$.

Локальне напруження м'язів передньої черевної стінки в зоні проекції сліпої кишки та апендиксу залежно від терміну вагітності спостерігали у 54 вагітних (20,93 \%). У вагітних I триместру в 25 випадках (71,43 \%; n = 35), в II триместрі у 20 вагітних $(10,53 \% ; n=190)$ і в III триместрі у 9 вагітних $(27,27 \% ; n=33)$.

Ми зіставили вищезазначені клінічні особливості перебігу ГА у вагітних із лабораторно-імунологічними показниками та визначили діагностичні маркери.

Так, у вагітних із катаральною формою ГА лейкоцитоз становив $10,7 \pm 0,33 * 10^{9}$, що на $2,9 * 10^{9}$ перевищує значення у групи порівняння $(\mathrm{p}<0,05)$.

Коефіцієнт де Рітіса становив $(1,30 \pm 0,02)$ ум.од. $(\mathrm{p}<0,05)$, щонезначно нижче від показників групипорівняння $1,33 \pm 0,05(\mathrm{p}<0,05)$ і здорових осіб $1,3 \pm 0,01$ $(\mathrm{p}<0,05)$. При цьому слід наголосити, що показники коефіцієнта де Рітіса $(1,30 \pm 0,02)$ ум. од. $(\mathrm{p}<0,001)$, ЛII $(1,3 \pm 0,02)$ ум. од. ( $<<0,001)$, ЯІІ $(0,1 \pm 0,07)$ ум. од. $(\mathrm{p}<0,001)$, ГІІ $(0,74 \pm 0,05)$ ум. од. $(\mathrm{p}<0,001)$ суттєво не відрізнілись від показників здорових осіб та вагітних групи порівняння. ТЗН становив $(34,22 \pm 0,57) \%$ $(\mathrm{p}<0,05)$, що перевищує показники групи порівняння $(20,22 \pm 0,12) \%$ у 1,69 раза (p $<0,05)$ і показники здорових осіб $(1,11 \pm 0,2) \%$ у 30,8 раза $(\mathrm{p}<0,05)$. При цьому встановлено підвищення кількості НГ з апоптичними змінами до $(24,22 \pm 0,34) \%$ відносно значень здорових осіб $(3,45 \pm 0,09) \%(\mathrm{p}<0,05)$ в і групи 
порівняння $(7,23 \pm 0,06) \%(\mathrm{p}<0,05)$. Дані відображено в таблиці 2.

Дані таблиці 2 свідчать про розвиток інфекційно-запальних процесів у вагітних з катаральною формою ГА, котрі потребували проведення негайного хірургічного лікування.

Для оцінки патогенетичних механізмів формування запальної реакції у вагітних 3 катаральним ГА ми провели дослідження неспецифічної антимікробної резистентності та імунологічної реактивності. При цьому вивчено особливості функціональної активності нейтрофільних гранулоцитів у НСТ-тесті: спонтанну та стимульовану ліпополісахаридом клітинної стінки E. coli як показника стану системи неспецифічної антимікробної резистентності, а саме фагоцитозу і його киснезалежної фази. У пацієнток з гострим катаральним апендицитом визначаються високі показники спонтанного НСТ-тесту - $(24,5 \pm 0,34) \%$ $(\mathrm{p}<0,05)$. Дані показники перевищують значення порівняльної групи $12,0 \pm 0,15$ і показники здорових осіб $11,3 \pm 0,11$ в 2 рази $(\mathrm{p}<0,05)$ і 2,2 рази $(\mathrm{p}<0,05)$ відповідно. Додаткова стимуляція ЛПС нейтрофільних гранулоцитів в індукованому НСТ-тесті призводила до зниження цих показників відносно референтних значеннь у 1,6 раза $(\mathrm{p}<0,05)$ і в 1,8 раза $(\mathrm{p}<0,05)$ відповідно. Коефіцієнт стимуляції склав $-17,3$.

При оцінці гуморальних реакцій імунітету вагітних із катаральним ГА виявлено такі особливості.

Рівень IgM становив $(1,90 \pm 0,11)$ г/л, що перевищує значення у вагітних із групи порівняння $(0,90 \pm 0,02)$ г/л в $2,11(\mathrm{p}<0,05)$ раза і значення здорових осіб $(0,86 \pm 0,05)$ г/л в $2,20(\mathrm{p}<0,05)$ раза. $\mathrm{Pi}-$ вень IgG становив $(15,40 \pm 0,41)$ г/л, що перевищує значення у вагітних групи порівняння $11,22 \pm 0,31$ в 1,37 раза $(p<0,05)$ i значення здорових осіб $(11,45 \pm 0,27)$ г/л в 1,34 раза $(\mathrm{p}<0,05)$.

Встановлено підвищення вмісту ЦІК $(24 \pm 0,12)$ ум. од. у вагітних із катаральним ГА щодо значень у вагітних групи порівняння $(13,4 \pm 0,10)$ ум. од. і здорових осіб $(12,0 \pm 0,11)$ ум. од. в 1,46 раза $(\mathrm{p}<0,05)$ і 2,0 раза $(\mathrm{p}<0,05)$ відповідно.
При цьому встановлено, що у пацієнток даної групи спостерігається підвищення вмісту Іл-1 до $(46,1 \pm 2,1)$ Пг/мл щодо показників контрольної групи $(28,1 \pm 1,1)$ Пг/мл і групи здорових осіб $(26,0 \pm 18,1)$ Пг/мл в 1,6 раза $(\mathrm{p}<0,05)$ і в 1,8 раза $(\mathrm{p}<0,05)$ відповідно.

Визначено підвищення концентрації ФНП до $(69,2 \pm 1,0)$ Пг/мл відносно показників групи порівняння $(25,2 \pm 1,0)$ Пг/мл і здорових осіб $(24,2 \pm$ $1,0)$ Пг/мл в 2,74 раза $(\mathrm{p}<0,05)$ і 2,85 раза $(\mathrm{p}<0,05)$ відповідно.

Встановлено підвищення вмісту прокальцитоніну до ( $\geq 2$ нг/мл) щодо референтних значень у порівняльній групі та групі здорових осіб $(<0,5)$ в 4 рази, що свідчить про можливість розвитку інфекційно-запальних процесів у пацієнток даної групи.

Дані відображено в таблиці 3.

У вагітних із флегмонозною формою ГА лейкоцитоз становив $14,7 \pm 0,33 * 10^{9}$, що на $6,8 * 10^{9}$ перевищує значення у групи порівняння (р <0,05). Показники коефіцієнта де Рітіса $(1,27 \pm 0,04)$ ум. од. $(\mathrm{p}<0,05)$ значно не відрізнялись від показників здорових осіб $(1,3 \pm 0,01)(\mathrm{p}<0,05)$ та вагітних групи порівняння $(1,33 \pm 0,05)(\mathrm{p}<0,05)$. Значення ГІІ $(0,74 \pm 0,05)$ ум. од. $(\mathrm{p}<0,05)$ значно не відрізнялись

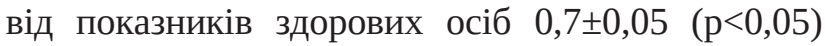
та вагітних групи порівняння $0,70 \pm 0,01(\mathrm{p}<0,05)$. Значення ЛІІ $(1,5 \pm 0,02)$ ум. од. $(\mathrm{p}<0,05)$ зросло на $15,38 \%$ відносно значень $(1,3 \pm 0,03)$ ум. од. $(\mathrm{p}<0,05)$ вагітних із групи порівняння та здорових осіб. Рівень ЯІІ $(0,2 \pm 0,05)$ ум. од. $(p<0,05)$ збільшився в 2 рази відносно здорових осіб та вагітних групи порівняння $(0,1 \pm 0,02)$ ум. од. $(\mathrm{p}<0,05)$.

Рівень ТЗН становив $(64,09 \pm 0,56) \%(\mathrm{p}<0,05)$, що перевищує показники групи порівняння $(20,22 \pm 0,12) \%$ у 3,17 раза $(p<0,05)$ і показники здорових осіб $(1,11 \pm 02) \%$ у 57,7 раза (р <0,05). При цьому встановлено підвищення кількості НГ 3 апоптичними змінами до $(45,16 \pm 0,35) \%(\mathrm{p}<0,05)$ відносно значень здорових осіб $(3,45 \pm 0,09) \%$ $(\mathrm{p}<0,05)$ в 13,1 раза і в 6,25 раза відносно значень групи порівняння $(7,23 \pm 0,06) \%(p<0,05)$. Дані відображеню в таблиці 4.

Таблиця 2. Показники неспецифічної резистентності та адаптаційного імунітету в пацієнток із катаральною формою ГА в дослідній групі $(n=38)$

\begin{tabular}{||c|c|c|c|c||}
\hline $\begin{array}{c}\text { Досліджувані } \\
\text { показники }\end{array}$ & $\begin{array}{c}\text { Одиниці } \\
\text { виміру }\end{array}$ & $\begin{array}{c}\text { Показники вагітних із } \\
\text { катаральним ГА } \\
\text { (n = 38) }\end{array}$ & $\begin{array}{c}\text { Показники вагітних } \\
\text { групи порівняння } \\
\text { (n = 174) }\end{array}$ & $\begin{array}{c}\text { Показники фізіологічної } \\
\text { норми (здорові особи) }\end{array}$ \\
\hline Спонтанний тест & $\%$ & $24,5 \pm 0,34$ & $12,0 \pm 0,15$ & $11,3 \pm 0,11$ \\
\hline Індукований тест & $\%$ & $7,2 \pm 0,12$ & $11,3 \pm 0,11$ & $12,8 \pm 0,34$ \\
\hline Токсогенна зернистість & $\%$ & $34,22 \pm 0,57$ & $20,22 \pm 0,12 * *$ & $1,11 \pm 02$ \\
\hline Кількість апоптозів & $\%$ & $24,22 \pm 0,34$ & $7,23 \pm 0,06 * *$ & $3,45 \pm 0,09$ \\
\hline
\end{tabular}


Таблиця 3. Особливості формування гуморальних реакцій у вагітних із катаральним ГА $(\mathrm{n}=38)$

\begin{tabular}{||c|c|c|c|c||}
\hline $\begin{array}{c}\text { Досліджувані } \\
\text { показники }\end{array}$ & $\begin{array}{c}\text { Одинниці } \\
\text { виміру }\end{array}$ & $\begin{array}{c}\text { Катаральна форма ГА } \\
(\mathrm{n}=38)\end{array}$ & $\begin{array}{c}\text { Група порівняння } \\
(\mathrm{n}=174)\end{array}$ & $\begin{array}{c}\text { Показники здорових } \\
\text { осіб }\end{array}$ \\
\hline IgM & г/л & $1,90 \pm 0,11$ & $0,90 \pm 0,02$ & $0,86 \pm 0,05$ \\
\hline IgG & г/л & $15,40 \pm 0,41$ & $11,22 \pm 0,31$ & $11,45 \pm 0,27$ \\
\hline IgA & г/л & $0,91 \pm 0,06$ & $0,79 \pm 0,04$ & $0,81 \pm 0,05$ \\
\hline IgE & г/л & $2,7 \pm 0,07$ & $2,1 \pm 0,01$ & $2,0 \pm 0,05$ \\
\hline ЦІК & ум. од. & $24 \pm 0,12$ & $13,4 \pm 0,10$ & $26,0 \pm 18,1$ \\
\hline Іл-1 & Пг/мл & $46,1 \pm 2,1$ & $28,1 \pm 1,1$ & $12,75 \pm 1,25$ \\
\hline Іл-2 & Пг/мл & $10,73 \pm 0,34$ & $12,22 \pm 1,12$ & $24,2 \pm 1,0$ \\
\hline ФНП & Пг/мл & $69,2 \pm 1,0$ & $25,2 \pm 1,0$ & $<0,5$ \\
\hline Прокальцитонін & нг/мл & $\geq 2$ & $<0,5$ & 0 \\
\hline Кріоглобуліни & Кількість & 2 & 1 & \\
\hline
\end{tabular}

Таблиця 4. Показники неспецифічної резистентності та адаптаційного імунітету в пацієнток із флегмонозною фрормою ГА в дослідній групі ( $\mathrm{n}=78)$

\begin{tabular}{||c|c|c|c|c||}
\hline $\begin{array}{c}\text { Досліджувані } \\
\text { показники }\end{array}$ & $\begin{array}{c}\text { Одиниці } \\
\text { виміру }\end{array}$ & $\begin{array}{c}\text { Показники вагітних } \\
\text { із флегмонозним } \\
\text { ГА (n = 78) }\end{array}$ & $\begin{array}{c}\text { Показники вагітних } \\
\text { групи порівняння } \\
\text { (n = 174) }\end{array}$ & $\begin{array}{c}\text { Показники } \\
\text { фізіологічної норми } \\
\text { (здорові особи) }\end{array}$ \\
\hline Спонтанний тест & $\%$ & $24,5 \pm 0,34 *, * *$ & $12,0 \pm 0,15$ & $11,3 \pm 0,11$ \\
\hline Індукований тест & $\%$ & $7,2 \pm 0,12^{*}, * *$ & $11,3 \pm 0,11$ & $12,8 \pm 0,34$ \\
\hline Токсогенна зернистість & $\%$ & $64,09 \pm 0,56 *, * *$ & $20,22 \pm 0,12 * *$ & $1,11 \pm 02$ \\
\hline Кількість апоптозів & $\%$ & $45,16 \pm 0,35^{*}, * *$ & $7,23 \pm 0,06 * *$ & $3,45 \pm 0,09$ \\
\hline \hline
\end{tabular}

У пацієнток з флегмонозним ГА спостерігали значне підвищення вмісту IgM $(2,11 \pm 0,21)$ г/л (p <0,05), що в 2,34 раза (p <0,05) i 2,45 (p<0,05) paза вище значень групи порівняння $(0,90 \pm 0,02)$ г/л $(\mathrm{p}<0,05)$ і здорових осіб $(0,86 \pm 0,05)$ г/л $(\mathrm{p}<0,05)$.

IgG підвищився до $(17,22 \pm 0,34)$ г/л $(\mathrm{p}<0,05)$. Ці значення перевищують показники $(11,22 \pm 0,31)$ г/л $(\mathrm{p}<0,05)$ вагітних порівняльної групи в 1,53 раза та показники $(11,45 \pm 0,27)(\mathrm{p}<0,05)$ здорових осіб в 1,5 раза $(\mathrm{p}<0,05)$.

Спостерігали підвищення вмісту IgA $(1,34 \pm$ $0,07)$ г/л $(\mathrm{p}<0,05)$ щодо значень у вагітних порівняльної групи $(0,79 \pm 0,04)$ г/л $(\mathrm{p}<0,05)$ в 1,7 раза $(\mathrm{p}<0,05)$ та здорових осіб $(0,81 \pm 0,05)$ г/л $(\mathrm{p}<0,05)$ в 1,65 раза $(\mathrm{p}<0,05)$.

Встановлено підвищення вмісту ЦІК $(41,2 \pm$ $0,34)$ ум. од. ( $<0,05)$ щодо значень групи порівняння $(13,4 \pm 0,10)$ ум. од. $(\mathrm{p}<0,05)$ і здорових осіб $(12,0 \pm 0,11)$ ум. од. $(\mathrm{p}<0,05)$ у $3,07(\mathrm{p}<0,05)$ і 3,43 $(\mathrm{p}<0,05)$ рази відповідно.

При флегмонозному ГА у вагітних спостерігали значне підвищення в сироватці крові Іл-1 $(54,3 \pm 1,7)$ Пг/мл $(\mathrm{p}<0,05)$ відносно групи порівняння $(28,1 \pm 1,1)$ Пг/мл $(\mathrm{p}<0,05)$ в 1,93 раза $(\mathrm{p}<0,05) \mathrm{i}$

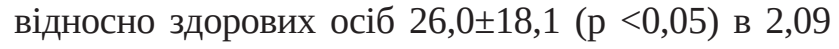

раза $(\mathrm{p}<0,05)$ відповідно. Встановлено значне підвищення концентрації ФНП $(81,3 \pm 1,12)$ Пг/мл (p <0,05) в сироватці крові відносно значень групи порівняння $(25,2 \pm 1,0)$ Пг/мл $(\mathrm{p}<0,05)$ в 3,23 раза $(\mathrm{p}<0,05)$ і здорових осіб $(24,2 \pm 1,0)$ Пг/мл $(\mathrm{p}<0,05)$ у 3,36 раза $(\mathrm{p}<0,05)$. Зростання прокальцитоніну склало (> 2 нг/мл) (р <0,05), що свідчить про розвиток інфекційних процесів і ризику генералізації. У вагітних групи порівняння та здорових осіб цей показник становить $(<0,5$ нг/мл), тобто в 4 рази менший $(\mathrm{p}<0,05)$.

Значення IgА підвищене незначно $(1,34 \pm 0,07)$ г/л $(\mathrm{p}<0,05)$ порівняно $з$ групою порівняння $(0,79 \pm$ $0,04)$ г/л $(\mathrm{p}<0,05)$ в 1,7 раза $(\mathrm{p}<0,05)$ і в 1,65 paза $(\mathrm{p}<0,05)$ порівняно з групою здорових осіб 0,81 $\pm 0,05(\mathrm{p}<0,05)$. Значення IgE підвищене незначно $(2,7 \pm 0,07)$ г/л $(\mathrm{p}<0,05)$ порівняно з групою порівняння $(2,1 \pm 0,01)$ г/л $(\mathrm{p}<0,05)$ в 1,29 раза $(\mathrm{p}<0,05)$ і в 1,35 раза $(\mathrm{p}<0,05)$ порівняно з групою

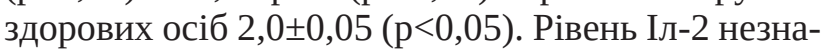
чно знижений $(11,11 \pm 0,56)$ г/л $(\mathrm{p}<0,05)$ порівняно з групою порівняння $(12,22 \pm 1,12)$ г/л $(\mathrm{p}<0,05)$ в 1,1 раза $(\mathrm{p}<0,05)$ і в 1,15 раза $(\mathrm{p}<0,05)$ порівняно з групою здорових осіб $12,75 \pm 1,25$ (p $<0,05)$. Дані наведено в таблиці 5. 
Таблиця 5. Особливості формування гуморальних реакцій у вагітних із фрлегмонозним ГА $(\mathrm{n}=78)$

\begin{tabular}{|c|c|c|c|c|}
\hline $\begin{array}{c}\text { Досліджувані } \\
\text { показники } \\
\end{array}$ & $\begin{array}{l}\text { Одинниці } \\
\text { виміру }\end{array}$ & $\begin{array}{c}\text { Флегмонозна форма ГА } \\
(\mathrm{n}=78)\end{array}$ & $\begin{array}{c}\text { Група порівняння } \\
(\mathrm{n}=174)\end{array}$ & $\begin{array}{c}\text { Показники здорових } \\
\text { осіб }\end{array}$ \\
\hline IgM & г\л & $2,11 \pm 0,21$ & $0,90 \pm 0,02$ & $0,86 \pm 0,05$ \\
\hline IgG & г\л & $17,22 \pm 0,34$ & $11,22 \pm 0,31$ & $11,45 \pm 0,27$ \\
\hline $\operatorname{Ig} \mathrm{A}$ & $\Gamma \backslash л$ & $1,34 \pm 0,07$ & $0,79 \pm 0,04$ & $0,81 \pm 0,05$ \\
\hline IgE & $\Gamma \backslash л$ & $2,7 \pm 0,07$ & $2,1 \pm 0,01$ & $2,0 \pm 0,05$ \\
\hline ЦІК & У.e. & $41,2 \pm 0,34$ & $13,4 \pm 0,10$ & $12,0 \pm 0,11$ \\
\hline Іл-1 & Пг/мл & $54,3 \pm 1,7$ & $28,1 \pm 1,1$ & $26,0 \pm 18,1$ \\
\hline Іл-2 & Пг/мл & $11,11 \pm 0,56$ & $12,22 \pm 1,12$ & $12,75 \pm 1,25$ \\
\hline ФНП & Пг/мл & $81,3 \pm 1,12$ & $25,2 \pm 1,0$ & $24,2 \pm 1,0$ \\
\hline Прокальцитонін & нг/Мл & $>2$ & $<0,5$ & $<0,5$ \\
\hline Кріоглобуліни & $\begin{array}{c}\text { Кількість } \\
\text { позитивних } \\
\text { результатів }\end{array}$ & 5 & 1 & 0 \\
\hline
\end{tabular}

Таким чином, серед усіх гострих хірургічних захворювань органів черевної порожнини у вагітних найчастіше зустрічається ГА - близько 30 \% випадків. Найпоширенішою дана патологія $€$ у вагітних у II триместрі - близько 74 \%, дещо рідше зустрічається в I та III триместрах - близько 13 \%. Найчастіше при ГА скаржаться на біль в животі, що, як правило, виникає раптово. У вагітних у I триместрі біль локалізується в правій здухвинній ділянці. Вагітні в II та III триместрах вагітності скаржаться на біль у ділянці пупка та епігастрії. При цьому інтенсивність болю нижча в II та III триместрах. В I триместрі у близько 77 \% випадків біль у животі супроводжуються диспептичними проявами, що ускладнює диференційну діагностику з гестозами першої половини вагітності.

Проявляються ознаки ендогенної інтоксакації, вони більш виражені за умови розвитку деструктивного ГА.

При катаральній та флегмонозній формі ГА підвищення рівнів лекоцитів крові, незначне зниження рівнів коефіцієнта де Рітіса, збільшення ЛII, ЯII, ГІІ, підвищення ТЗН та апоптичних форм нейтрофілів, збільшення активності нейтрофілів у спонтанному та зниження їх активності в індукованому НСТ-тесті свідчать про напруження клітинного імунітету, підвищений рівень запальних реакцій в організмі вагітної та високу ймовірність розвитку інфекційно-запальних ускладнень. Вищевизначене сприяє вирішенню питання стосовно високої вірогідності проведення хірургічного втручання уже одразу при госпіталізації хворої до стаціонару. Підвищенний рівень у таких хворих Ig M, Ig G свідчить про напруження адаптаційного протиінфекційного гуморального імунітету. Під- вищений рівень медіаторів запалення ПРК, ФНП, Іл-1, ЦІК, також підтверджує розвиток інфекційно-запальних процесів в організмі вагітної. При цьому незначне збільшення рівня IgA, IgE на фоні незначного зниження рівня Іл-2 та збільшення рівня кріоглобулінів у помірній кількості також свідчить про відсутність значних токсичних процесів і превалювання інфекційно-запальних реакцій в організмі вагітної з ГА. Таким чином, при лабораторному та імунологічному дослідженні виявлено превалювання інфекційно-запальних процесів над токсичними у вагітних із ГА.

Висновки. 1. Прояви гострого апендициту у вагітних $є$ атиповими, що вимагають алгоритму діагностичного моніторингу на висоті токолітичної терапії.

2. Анатомічне розташування червоподібного відростка з запальними процесами корелює з лабораторно-імунологічним профілем та потребує персоналізованого строкового лікування.

3. Морфологічна картина апендициту у вагітних не є закономірною залежно від проявів анатомічного розташування та триместру.

4. Ретроспективний аналіз зіставлення семіотики гострої хірургічної патологї̈ залежно від триместру визначає алгоритм послідовної тактики щодо проявів морфологічних форм апендициту як вибір методу попередження ускладнень при вагітності.

Перспективи подальших досліджень. Детальна оцінка клінічних та параклінічних показників дасть змогу сформувати діагностичний неінвазивний алгоритм гострого апендициту у вагітних для достовірного встановлення діагнозу залежно від триместру вагітності. 


\section{СПИСОК ЛІТЕРАТУРИ}

1. Діагностика і лікування гострого ретроперитонеального апендициту у жінки на 36-37-му тижні вагітності / Б. С. Келеман, Г. В. Гула, В. П. Федоренко [та ін.] // Львівський мед. часоп. - 2009. - Т. 15, № 2. - С. 58-63.

2. Острый флегмонозный аппендицит и беременность 39 недель / Ф. А. Греджев, Т. Ю. Бабич, Ю. Л. Куницкий [и др.] // Вестник неотложной и восстановительной медицины. 2005. - Т. 6, № 4. - С. 699-700.

3. Острые хирургические заболевания у беременных, особенности диагностики и тактики лечения / И. И. Климович, В. П. Страпко, А. С. Оганесян [и др.] // Актуальные вопросы акушерства и гинекологии : материалы Республ. научнопракт. конф. с межд. участием, 20-21 октября 2011 г. - Гродно, 2011. - Р. 73-75.

4. Шапкин Ю. Г. Современные технологии в диагностике острого аппендицита при беременности / Ю. Г. Шапкин, Г. В. Ливадный, Д. В. Маршалов // Бюллетень медицинских интернет-конференций. - 2011. - Т. 1, № 2. - С. 29-37. 5. Шайрамарданов Р. Ш. Инструментальные методы исследования в диагностике острого аппендицита у беременных // Р. Ш. Шайрамарданов, Р. Ф. Гумаров // Казанский мед. журнал. - 2010. - Т. 91, № 5. - С. 622-625.

6. Barnes S. L. Appendectomy during early pregnancy: what is the preferred surgical approach / S. L. Barnes, T .W. Carver, J. Antevil // Am. Surg. - 2005. - Vol. 71 (10). - P. 809-812.

7. Fozan H. A. 2002. Safety and risks of laparoscopy in pregnancy / H. A. Fozan, T. Tulandi // Curr. Opin. Obstet. Gynecol. - 2002. - Vol. 14 (4). - P. 375-379.

8. Hodjati H. Location of the appendix in the gravid patient: a re-evolution of the established concept / H. Hodjati, T. Kazerooni // Int. J. Gynaecol. Obstet. - 2003. - Vol. 81 (3). - P. 245-247. 9. Lyass S. Is laparoscopic appendectomy safe in in pregnant women? / S. Lyass, A. Rikarsky, V. H. Eisenberg // Surg. Endoscop. - 2001. - Vol. 15 (4). - P. 377-379.

\section{REFERENCES}

1. Keleman, B.S., Hula, H.V., \& Fedorenko, V.P. 2009. Diahnostyka i likuvannia hostroho retroperytonealnoho apendytsytu u zhinky na 36-37-mu tyzhni vahitnosti [Diagnosis and treatment of acute retroperitoneal appendicitis in women at 36-37 weeks of pregnancy]. Lvivskyi med. Chasopys - Lviv Medical Journal, 15 (2), 58-63 [in Ukrainian].

2. Gredzhev, F.A., Babich, T.Yu., \& Kunitskiy, Yu.L. (2005). Ostryi flegmonoznyy appenditsit i beremennost 39 nedel [Acute phlegmonous appendicitis and 39 week pregnancy]. Vestnik neotlozhnoy $i$ vosstanovitelnoy meditsiny - Journal of Emergency and Restorable Medicine, 6 (4), 699-700 [in Russian].

3. Klimovich, I.I., Strapko, V.P., \& Oganesyan, A.S. (2011). Ostrye khirurgicheskie zabolevaniya u beremennykh, osobennosti diagnostiki i taktiki lecheniya [Acute surgical diseases in pregnant women, especially diagnosis and treatment tactics]. Aktualnye voprosy akusherstva i ginekologii: materialy Respubl. nauchnoprakt. konf. s mezhd. uchastiem - Actual Issues of Obstetrics and Gynecology: Materials of Respubl. Scientific and Practical Conf. with International Participation, (pp. 73-75) [in Russian].

4. Shapkin, Yu.G., Livadnyy, G.V., \& Marshalov, D.V. (2011). Sovremennye tekhnologii v diagnostike ostrogo appenditsita pri beremennosti [Modern technologies in the diagnosis of acute appendicitis in pregnancy]. Byulleten meditsinskikh internetkonferentsiy - Journal of Medical Internet Conferences, 1 (2), 2937 [in Russian].

5. Shairamardanov, R.Sh., \& Gumarov, R.F. (2010). Instrumentalnye metody issledovaniya $\mathrm{v}$ diagnostike ostrogo appenditsita u beremennykh [Instrumental research methods in the diagnosis of acute appendicitis in pregnant women]. Kazanskiy med. Zhurnal - Kazan Medical Journal, 91 (5), 622-625 [in Russian].

6. Barnes, S.L., Carver, T.W., \& Antevil, J. (2005). Appendectomy during early pregnancy: what is the preferred surgical approach. Am. Surg., 71 (10), 809-812.

7. Fozan, H.A., Tulandi, T. 2002. Safety and risks of laparoscopy in pregnancy. Curr. Opin. Obstet. Gynecol.,14 (4), 375-379.

8. Hodjati, H., \& Kazerooni, T. (2003). Location of the appendix in the gravid patient: a re-evolution of the established concept. Int. J. Gynaecol. Obstet., 81 (3), 245-247.

9. Lyass, S., Rikarsky, A., \& Eisenberg, V.H. (2001). Is laparoscopic appendectomy safe in in pregnant women? Surg. Endoscop., 15 (4), 377-379.

\section{MANIFESTATIONS OF ACUTE APPENDICITIS SEMIOTICS IN DEPENDENCE FROM ITS LOCATION AND TRIMESTER OF PREGNANCY}

The aim of the work: to analyze the clinical course of acute appendicitis and laboratory parameters of inflammation in pregnant women, depending on the location of the appendix and the trimester of pregnancy to determine the treatment and prevention of complications during pregnancy.

Materials and Methods. The clinical course and paraclinical parameters were evaluated in 258 pregnant women with acute appendicitis who were treated at the clinical clinics in Kyiv and 391 pregnant women without acute surgical pathology, which made the comparison group. Among the biochemical data, the level of immunoglobulins M, G, A, E, circulating immune complexes, tumor necrosis factor, cryoglobulins, procalcitonin, interleukin 1, 2 as well as parameters of non-specific resistance of the organism and adaptive immunity were investigated. 
Results and Discussion. In the first trimester, $68.57 \%$ of patients noted a sudden onset of pain, $63.68 \%$ in the second and $69.7 \%$ in the third. The combination with nausea and single or double vomiting is set in $77.14 \%$, $47.89 \%$ and $36.36 \%$, respectively. Signs of endogenous intoxication were found in $20.0 \%, 45.26 \%, 57.58 \%$ of pregnant women in three trimesters, respectively. In the second and third trimesters of pregnancy, the determination of pain at the points of McBurney, Lanca was ineffective in $90 \%$ of cases. Among the biochemical indicators, the increase in the content of procalcitonin was 4 times, the concentration of TNF was 2.74 times, the IL- 1 content was 1.6 times, the content of the CIC was 1.46, and the levels of IgM and IgG (2.11 times and 1.37 times), respectively), relative to the indicators of the control group.

Key words: acute appendicitis; pregnancy; immunoglobulins; interleukins; cryoglobulins.

\section{Н. М. СТЕЦЬ, В. М. ЧЕРНЕНКО}

Национальный медицинский университет имени А. А. Богомольца, Киев

\section{ПРОЯВЛЕНИЯ СЕМИОТИКИ ОСТРОГО АППЕНДИЦИТА В ЗАВИСИМОСТИ ОТ ЕГО РАЗМЕЩЕНИЯ И ТРИМЕСТРА БЕРЕМЕННОСТИ}

Цель работы: провести анализ клинического течения острого аппендицита и лабораторных показателей воспаления у беременных в зависимости от расположения аппендикса и триместра беременности для определения тактики лечения и предупреждения осложнений при беременности.

Материалы и методы. Оценены клиническое течение и параклинические показатели в 258 беременных с острым аппендицитом, находившихся на лечении в клинических больницах города Киева и 391 беременной без острой хирургической патологии, что составили группу сравнения. Среди биохимических данных исследован уровень иммуноглобулинов M, G, A, E, циркулирующих иммунных комплексов, фактора некроза опухолей, криоглобулинов, прокальцитонина, интерлейкина-1, 2, а также показателей неспецифической резистентности организма и адаптационного иммунитета.

Результаты исследований и их обсуждение. Внезапное начало боли отмечали в I триместре у 68,57 \% пациенток, во II 63,68 \% и 69,7 \% в третьем. Сочетание с тошнотой и одно- или двукратной рвотой установлено в 77,14 \%, 47,89 \% и 36,36 \% соответственно. Признаки эндогенной интоксикации установлено в 20,0%, 45,26 \%, 57,58 \% беременных в трех триместрах соответственно. Во II и III триместрах беременности определение болезненности в точках Мак-Бурнея, Ланца было неэффективным в 90 \% случаях. Среди биохимических показателей установлено повышение содержания прокальцитонина в 4 раза, концентрации ФНО 2,74 раза, содержания Ил-1 в 1,6 раза, содержания ЦИК в 1,46 и уровней IgM и IgG (в 2,11 раза и 1,37 раза соответственно) по показателям контрольной группы.

Ключевые слова: острый аппендицит; беременность; иммуноглобулины; интерлейкины; криоглобулины. 